\title{
Influence of Garlic and Hot Pepper Sauce on the Quality of Marinated Anchovies during 7 Months at $4^{\circ} \mathrm{C}$ Storage
}

\author{
Bilge Bilgin Ficicilar ${ }^{1, a, *}$, Hüseyin Genccelep ${ }^{2, b}$ \\ ${ }^{1}$ Department of Fisheries Technology Engineering, Faculty of Marine Sciences, Ordu University, 52200 Ordu, Turkey \\ ${ }^{2}$ Department of Food Engineering, Faculty of Engineering, Ondokuz Mayis University, 55270 Samsun, Turkey \\ *Corresponding author

\begin{tabular}{l|l}
\hline A R T I C L E I N F O & A B S T R A C T \\
\hline Research Article & $\begin{array}{l}\text { Marinated anchovies produced in a fish processing plant in Samsun province (with 3\% garlic and } \\
3 \% \text { hot pepper sauce) were filled in plastic jars and vacuum packed. Physical, chemical and } \\
\text { microbiological analyses of the samples were performed to determine the effects of garlic and hot } \\
\text { pepper sauce on the shelf life of marinated anchovies. Total viable bacteria count (TVB), lactic acid } \\
\text { bacteria count (LAB), Enterobacteriaceae count, biogenic amines (histamine, tyramine, cadaverine, } \\
\text { putrescine, tryptamine), pH, total volatile basic nitrogen (TVB-N), thiobarbituric acid (TBA) } \\
\text { analysis were performed during 7 months of storage at } 4{ }^{\circ} \mathrm{C} \text {. Comparing the control group with garlic } \\
\text { added and hot pepper sauce added samples, garlic addition reduced the microbial growth and } \\
\text { provided that the samples retained their physicochemical properties (TBA, TVB-N) for a longer } \\
\text { period time. The amounts of biogenic amines were determined less in garlic added samples. }\end{array}$ \\
$\begin{array}{l}\text { Received : } 31 / 10 / 2019 \\
\text { Accepted : } 07 / 01 / 2020\end{array}$ & $\begin{array}{l}\text { Keywords: } \\
\text { Marinated anchovies }\end{array}$
\end{tabular}

Hot chilli pepper sauce

Biogenic amines

Shelf life

bilgebilginficicilar@gmail.com

https://orcid.org/0000-0002-7217-5905

|b@genccelep@hotmail.com

(iD) ttps://orcid.org/0000-0002-8689-7722

\section{Introduction}

Anchovy is the most popular and most caught fish in Turkey with 96,451.7 tons in 2018. Approximately 50000 tons are consumed as fresh or processed for human consumption while the rest is used in fish feed and byproduct manufacture (TUİ, 2018). Anchovy is a fatty fish (fat amount ranging between 7.9-16.32\%) which makes it a suitable fish for the marination process (Oksuz et al., 2010).

Marinades are semi-preserved food products, which can be produced from fresh, frozen or salted fish. Marination is done by the action of acetic acid and salt for a determined period time. Marination procedure aims to extend the shelf life of fish while improving its textural, sensorial and structural properties through the degradation of proteins and fats in the fish meat. Cathepsins in fish meat form peptides, nucleotides, free amino acids by the protein hydrolyzation. Fish marinades can be sectioned into three groups according to the heat application performed during the marination process. These fish marinades are cold, fried, and cooked. Cold marinades make up more than $90 \%$ of Turkish and European marinated fish market. Having high nutritional value, desired taste and no requirement to cook, marinated anchovy consumption is increasing in Turkey (Baygar et al., 2012).

Anchovies are rich in polyunsaturated fatty acids, which makes it vulnerable to oxidation. In order to produce marinated anchovies for 12 months a year, freezing is an essential process. The freezing procedure is known to degrade proteins, oxidate lipids, and pigments. The oxidation process reduces nutritional value and leads to deteriorative changes in food aroma, texture, and color with potentially toxic products (Turhan et al., 2009). Synthetics antioxidants are not preferred regarding the concerns about the toxicological risks among with the demand of consumers for the natural products. Since marinated anchovies are produced in all months of the year and are an important export product, natural additives have been investigated in order to minimize the negative effects of the anchovy during freezing and storage of marinated anchovies. In our study garlic and hot chilli pepper sauce were used in order to give a desired aroma and color with reducing lipid oxidation and inhibiting the formation of possible toxic products like biogenic amines. 


\section{Materials and Methods}

\section{Raw Material}

Anchovy (Engraulis encrasicholus) was caught in the Black Sea near Samsun Province in the winter of 2016. Following the harvest, anchovies were transferred to the fish processing facility (North Point Black Sea Fish Co., Samsun, Turkey) in icy polystyrene foam fish boxes. Fresh anchovies were frozen $\left(-35^{\circ} \mathrm{C}\right)$ for about 24 hours in cold rooms and kept at $-18^{\circ} \mathrm{C}$ until the day of processing. Frozen fish were brought to the processing area and melted under running filtered tap water about $8-10^{\circ} \mathrm{C}$. Fishes were weighted in the boxes. Evisceration and gutting were completed under running tap water. Cleaned fish were brought to the marination room on the same day. The marination of anchovies was done with brine (9\% salt and $4.2 \%$ vinegar) in fish baskets for a day at $10^{\circ} \mathrm{C}$. Marinated fish were drained and placed in a round plastic jar. Sunflower oil and garlic or hot chilli pepper sauce were added at this stage. Three different products were manufactured. Samples were stored in a refrigerator $\left(4^{\circ} \mathrm{C}\right)$ and analyzed at 0,1, 2, 3, 7 months of storage. Photograph of samples produced is in Figure 1.

\section{Proximate Analysis}

Moisture, protein, lipid and ash content were determined triplicate in raw and marinated anchovies. Moisture content was calculated as \% on samples (2-5g) dried in an oven overnight at $105^{\circ} \mathrm{C}$ (AOAC, 2000). Protein content was determined using Kjeldahl Method (AOAC, 2002a). Constant of 6.25 was used in order to calculate the amount of crude protein. Ash content was measured by burning samples at $550^{\circ} \mathrm{C}$ for 5 hours and $\%$ ash was determined by quantification of weight loss (AOAC, 2002b). Lipid content was determined according to (AOAC, 1990).

\section{Chemical Analysis}

Distillation procedure (Buchi Distillation Unit K-350) was used to determine the total volatile basic nitrogen (TVB-N) amount of samples (Antonacopoulos et al., 1989). Results were calculated as $\mathrm{mg} / 100 \mathrm{~g}$ sample. $10 \mathrm{~g}$ of fish sample was added in $100 \mathrm{~mL}$ of distilled water. Homogenization was performed with an Ultraturrax (IKA T18). $\mathrm{pH}$ of samples was measured with a $\mathrm{pH}$ meter equipped with an electrode (Cyberscan PC 510, Singapore). Thiobarbituric acid amount (TBA) was determined according to the procedure proposed by (Tarladgis et al., 1960) and lipid oxidation products were expressed as malondialdehyde (MDA, $\mathrm{mg} / \mathrm{kg}$ ) equivalents.

\section{Microbiological Analysis}

Marinated anchovy samples (25g) were aseptically added to a stomacher bag containing $225 \mathrm{~mL}$ of $0.85 \%$ sterile saline solution and homogenized for 3 minutes using a masticator at highest level (Stomacher, IUL Instrument, Spain). Lactic acid bacteria, total viable bacteria and Enterobacteriaceae were determined. MRS (De Man Rogosa Sharpe) agar was used for the enumeration of lactic acid bacteria and plates were incubated for 5 days at $30^{\circ} \mathrm{C}$. Plate count agar (PCA) was used for the enumeration of the total viable count and incubated for 2 days at $30^{\circ} \mathrm{C}$. Aliquots of $1 \mathrm{~mL}$ of each dilution were delivered to petri dishes using pour plate method. For total viable bacteria, and Enterobacteriaceae count, plate count agar (PCA), and violet red bile agar (VRBA) were prepared. Plates were incubated for 2 days at $30^{\circ} \mathrm{C}$ for total viable bacteria count (PCA) and 24 hours (VRBA) at $37^{\circ} \mathrm{C}$ for Enterobacteriaceae count. Anaerobic incubator was used for the incubation of lactic acid bacteria and Enterobacteriaceae. Microbiological data were transferred into logarithms of the number of colony-forming units ( $\log$ cfu) per gram of fish sample.

\section{Determination of Biogenic Amines}

Samples for biogenic amines determination were stored at $-18^{\circ} \mathrm{C}$ until analysis. Biogenic amine content of the samples was determined according to the method of (Eerola et al., 1996). Biogenic amines were extracted from $2.0 \mathrm{~g}$ samples with $0.4 \mathrm{M}$ perchloric acid and homogenization was done with ultraturrax (IKA T18) blender. Centrifugation was performed at $3000 \mathrm{rpm}$ for 10 minutes and the supernatant was collected. The supernatant was brought to $25 \mathrm{~mL}$ with $0.4 \mathrm{M}$ perchloric acid. This solution was filtered through the whatman number 1 filter paper. A $1 \mathrm{~mL}$ of supernatant of the standard solution was transferred into $10 \mathrm{~mL}$ glass tubes and mixed with $20 \mathrm{~mL}$ of internal standard (1,7-diaminoheptane, $0.3 \mathrm{~mL}$ saturated aqueous solution of $\mathrm{Na}_{2} \mathrm{CO}_{3}$ ) and $0.2 \mathrm{~mL} 2 \mathrm{M} \mathrm{NaOH}$. Derivatization was completed with $2 \mathrm{~mL}$ of dansyl chloride. The derivatization was carried out by incubation for 45 minutes in alkaline media and the sample was finally dissolved in acetonitrile. After the reaction, the mixture was cooled and the dansylation reaction was interrupted using $0.1 \mathrm{~mL}$ of ammonia $(25 \% \mathrm{v} / \mathrm{v})$.

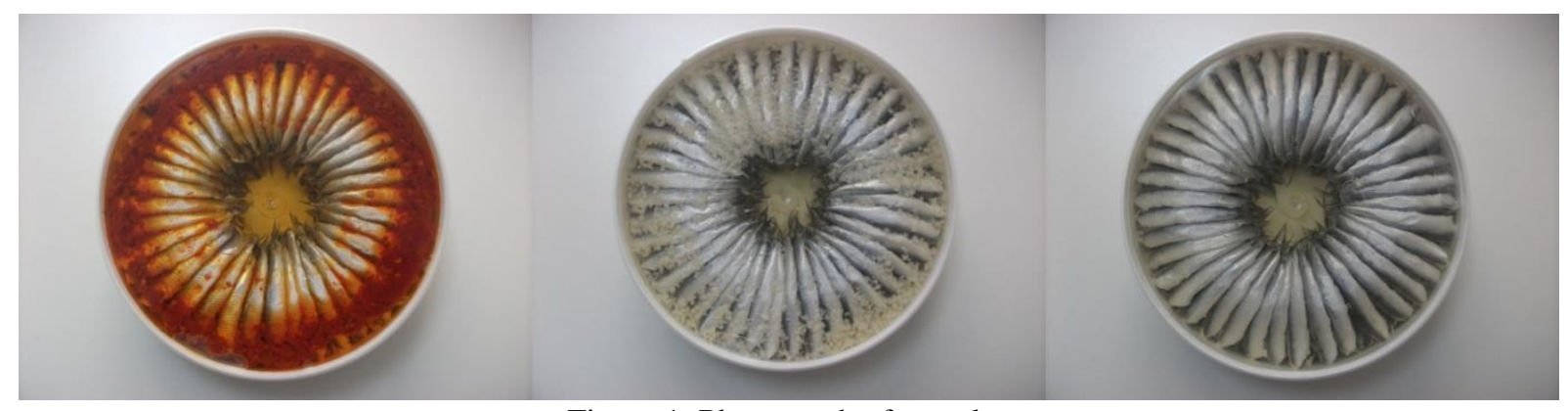

Figure 1. Photograph of samples

From left to right hot chilli pepper sauce marinated anchovies $(\mathrm{H})$, garlic added marinated anchovies (G), marinated anchovies (C). 
The $20 \mu \mathrm{L}$ of standard and sample derivates were injected to HPLC (Shimadzu Corporation, Kyoto, Japan). The gradient-elution system was $0.1 \mathrm{M}$ ammonium acetate as solvent $\mathrm{A}$ and acetonitrile as solvent $\mathrm{B}$. The gradientelution program began at $50 \%$ solvent B and ended at $90 \%$ solvent B in 25 min. Equilibration of the system was done for 15 minutes before the following analysis. The column temperature was adjusted to $40^{\circ} \mathrm{C}$ and the flow rate was 1.0 $\mathrm{mL} / \mathrm{min}$. and. A $20 \mu \mathrm{L}$ sample was injected. Column effluent was monitored at $254 \mathrm{~nm}$ with $550 \mathrm{~nm}$ as reference using the HPLC system with a column Spherisorb ODS2 150A, $150 \times 4.60 \mathrm{~mm}$ (Waters, Milford, MA, USA), HPLC (Shimadzu Corporation, Kyoto, Japan) (CBM-20A system control unit, LC-20AT pomp unit, SIL-20A35 autosampler, SPD-M20A PDA detector and a computer including the Shimadzu package program). The quantitative determinations were carried out with an internal standard (1.7-diaminoheptane) method, by using peak areas. Biogenic amine contents were stated as $\mathrm{mg} / \mathrm{kg}$. The limit of detection was between $0.010-0.060 \mu \mathrm{g} / \mathrm{mL}$ and limits of quantification (LOQ) were between $0.020-0.150$ $\mu \mathrm{g} / \mathrm{mL}$ for different biogenic amines.

\section{Statistical Analyses}

Two- way analyses of variance was used for all of the statistical analysis (SPSS Version 21 for Macintosh (SPSS Inc., 119 Chicago, IL, USA, 2014). $\mathrm{P} \leq 0.05$ value was used to identify significant differences.

\section{Results and Discussion}

\section{Proximate Analysis}

Table 1 shows the proximate properties of raw and marinated anchovies. In this study, the marination process led to an increase in protein, lipid, and ash percentage of anchovies by reducing the water amount. Ozden (2005) did a similar study on marinated anchovy and determined the total protein percentage as $18.02 \%$ in fresh fish (raw material) and $19.10 \%$ in marinated anchovies. İnanl 1 Güral et al. (2010) determined $11.45 \%$ fat, $20.34 \%$ protein, $65.30 \%$ moisture, $2.05 \%$ ash in marinated anchovies. The proximate composition $(72.10 \%$ moisture, $19.87 \%$ protein, $4.84 \%$ lipid, $1.54 \%$ ash) was reported by (Arik et al., 2002) for marinated fish.

\section{Chemical Analysis}

Results of the chemical analysis of raw and marinated anchovies are given in Table 2 .

TBA value of raw material was found to be $6.53 \mathrm{mg}$ MDA/kg. Anchovies (Engraulis encrasicolus) used in our study were kept frozen in cold rooms $\left(-18^{\circ} \mathrm{C}\right)$ for 6 months. High initial TBA value of raw anchovies could be related to frozen storage (Karami et al., 2013). TBA value of marinated anchovy (control) decreased from $7.78 \mathrm{mg}$ $\mathrm{MDA} / \mathrm{kg}$ to $7.20 \mathrm{mg} \mathrm{MDA} / \mathrm{kg}$ at the end of the storage period of 7 months while TBA value of anchovy marinade with garlic increased from $6.36 \mathrm{mg} \mathrm{MDA} / \mathrm{kg}$ to 6.62 MDA $/ \mathrm{kg}$ during 7 months of storage. TBA value of anchovy marinade with hot chilly pepper sauce increased from $6.99 \mathrm{mg} \mathrm{MDA} / \mathrm{kg}$ to $7.88 \mathrm{mg} \mathrm{MDA} / \mathrm{kg}$. As can be observed from the results of the current study, there is a trend towards an increase in TBA values up to a certain point during the storage period, followed by either a lower increase rate or a decrease in these values. At the end of 7 months of storage at $4^{\circ} \mathrm{C}$, the highest TBA value was seen in marinated anchovies with hot chilly pepper sauce, followed by marinated anchovies with garlic. These findings were in agreement with previous studies which mentioned that TBA value may be reduced along with the storage time (Duyar et al., 2009; Goulas et al., 2007).

Table 1. Proximate composition (w/w \%) of raw and marinated anchovies.

\begin{tabular}{l|rrrr}
\hline \multicolumn{1}{c|}{ Component } & Raw material & \multicolumn{1}{c}{ C } & \multicolumn{1}{c}{ G } \\
\hline Water & $70.77 \pm 0.73^{\mathrm{c}}$ & $64.25 \pm 0.94^{\mathrm{a}}$ & $67.86 \pm 0.52^{\mathrm{b}}$ & $64.94 \pm 0.45^{\mathrm{a}}$ \\
Lipid & $10.24 \pm 0.64^{\mathrm{a}}$ & $13.99 \pm 0.50^{\mathrm{c}}$ & $12.65 \pm 0.49^{\mathrm{b}}$ & $12.60 \pm 0.80^{\mathrm{b}}$ \\
Ash & $1.55 \pm 0.05^{\mathrm{a}}$ & $2.53 \pm 0.11^{\mathrm{b}}$ & $2.57 \pm 0.12^{\mathrm{b}}$ & $2.64 \pm 0.04^{\mathrm{b}}$ \\
Protein & $18.67 \pm 0.57^{\mathrm{a}}$ & $23.47 \pm 0.40^{\mathrm{c}}$ & $21.66 \pm 0.67^{\mathrm{b}}$ & $21.52 \pm 1.92^{\mathrm{b}}$ \\
\hline
\end{tabular}

C: Marinated anchovies (control), G: Garlic added marinated anchovies, H: Hot chilly pepper sauce added marinated anchovies, Results are mean and standard derivation of three samples

Table 2. Chemical analysis results of marinated anchovies

\begin{tabular}{|c|c|c|c|c|c|c|c|c|c|}
\hline \multirow{4}{*}{ Time } & \multicolumn{9}{|c|}{ Parameter } \\
\hline & \multicolumn{3}{|c|}{ TBA } & \multicolumn{3}{|c|}{ TVB-N } & \multicolumn{3}{|c|}{$\mathrm{pH}$} \\
\hline & \multicolumn{9}{|c|}{ Sample } \\
\hline & $\mathrm{C}$ & $\mathrm{G}$ & $\mathrm{H}$ & $\mathrm{C}$ & $\mathrm{G}$ & $\mathrm{H}$ & $\mathrm{C}$ & $\mathrm{G}$ & $\mathrm{H}$ \\
\hline \multirow{2}{*}{ Day 0} & $7.78^{\mathrm{bB}}$ & $6.36^{\mathrm{bA}}$ & $6.99^{\mathrm{abA}}$ & $7.97^{\mathrm{aA}}$ & $7.89^{\mathrm{aA}}$ & $9.03^{\mathrm{aA}}$ & $3.82^{\mathrm{cA}}$ & $3.91^{\mathrm{cA}}$ & $3.85^{\mathrm{cA}}$ \\
\hline & $(0.36)$ & $(0.78)$ & $(0.20)$ & $(0.42)$ & (1.12) & $(0.88)$ & $(0.05)$ & $(0.06)$ & $(0.05)$ \\
\hline \multirow{2}{*}{ Month 1} & $5.87^{\mathrm{aA}}$ & $5.85^{\mathrm{abA}}$ & $7.28^{\mathrm{aB}}$ & $9.07^{\mathrm{aAB}}$ & $7.48^{\mathrm{aA}}$ & $9.73^{\mathrm{aB}}$ & $3.62^{\mathrm{aA}}$ & $3.67^{\mathrm{abA}}$ & $3.54^{\mathrm{aA}}$ \\
\hline & $(0.24)$ & $(0.10)$ & $(0.22)$ & $(0.69)$ & $(0.80)$ & (1.66) & $(0.01)$ & $(0.02)$ & $(0.13)$ \\
\hline \multirow{2}{*}{ Month 2} & $5.91^{\mathrm{Aab}}$ & $5.12^{\mathrm{aA}}$ & $6.36^{\mathrm{aB}}$ & $9.09^{\mathrm{aA}}$ & $11.75^{\mathrm{bA}}$ & $11.02^{\mathrm{aA}}$ & $3.72^{\mathrm{bA}}$ & $3.62^{\mathrm{aA}}$ & $3.70^{\mathrm{bA}}$ \\
\hline & $(0.09)$ & $(0.39)$ & $(0.94)$ & $(0.71)$ & $(2.61)$ & $(0.97)$ & $(0.21)$ & $(0.08)$ & (0.08) \\
\hline \multirow{2}{*}{ Month 3} & $5.32^{\mathrm{aA}}$ & $6.39^{\mathrm{bB}}$ & $7.00^{\mathrm{abB}}$ & $20.90^{\mathrm{bA}}$ & $19.30^{\mathrm{cA}}$ & $18.10^{\mathrm{bA}}$ & $3.76^{\mathrm{bcA}}$ & $3.74^{\mathrm{bA}}$ & $3.70^{\mathrm{bA}}$ \\
\hline & $(1.30)$ & $(0.50)$ & $(0.21)$ & $(0.85)$ & (1.54) & $(2.40)$ & $(0.01)$ & $(0.05)$ & (0.01) \\
\hline \multirow{2}{*}{ Month 7} & $7.20^{\mathrm{bA}}$ & $6.62^{\mathrm{aB}}$ & $7.88^{\mathrm{bB}}$ & $22.47^{b A}$ & $21.00^{\mathrm{cA}}$ & $22.66^{\mathrm{cA}}$ & $4.12^{\mathrm{dAB}}$ & $4.07^{\mathrm{dA}}$ & $4.22^{\mathrm{dB}}$ \\
\hline & $(0.20)$ & $(0.20)$ & $(0.36)$ & (1.28) & $(1.00)$ & (1.53) & $(0.06)$ & $(0.07)$ & (0.03) \\
\hline
\end{tabular}

Superscript upper case letters $\left({ }^{\mathrm{A}, \mathrm{B},}\right)$ indicate difference among groups $(\mathrm{P}<0.05)$; Superscript lower case letters $\left(^{\mathrm{a}, \mathrm{b}, \mathrm{c}, \mathrm{d}}\right)$ indicate difference among storage period $(\mathrm{P}<0.05)$; M:Marinated anchovies (control), G:Garlic added marinated anchovies, H:Hot chilly pepper sauce added marinated anchovies; Results are mean and standart derivation of three samples. 
Considering that TBA value is a measure of malonaldehyde content, which is not durable for long periods of time decrease in TBA values is observed in MDA, and proteins, amino acids, nucleic acids, aldehydes, carbohydrates, glycogen, etc. It may be caused by the interaction of the substances reported, resulting in a lower amount of free MDA (Gomes et al., 2003). Allicin component garlic is known for its antioxidant properties. This effect is performed by scavenging reactive oxygen substances, and slowing down lipid peroxidation. Schormüller (1969) reported the consumption limit of TBA for fishes as $8 \mathrm{MDA} \mathrm{mg} / \mathrm{kg}$. According to our results, this value was not reached for all of the marinated anchovy samples at 7 months of storage at refrigerated temperature.

As shown in Table 2, TVB-N values of marinated anchovies increased gradually with the time of storage for all lots of marinated products. Based on the TVB-N limit of $35 \mathrm{mg} \mathrm{N} / 100 \mathrm{~g}$, none of the samples exceed this value throughout the storage at refrigerated temperature for 7 months. The initial (day 0) TVB-N value of the control sample was $7.97 \mathrm{mg} / 100 \mathrm{~g}$. TVB-N values increased progressively with time of storage at $4{ }^{\circ} \mathrm{C}$ for all treatments and reached $22.47,21.00$, and $22.66 \mathrm{mg} / 100 \mathrm{~g}$ for control, $\mathrm{G}$ and $\mathrm{H}$ groups, respectively. The addition of garlic and hot chilli sauce had no significant effect $(\mathrm{P}>0.05)$ on TVB$\mathrm{N}$ values of samples at the end of storage. Kocatepe et al. (2019) reported the TVB-N value of garlic essential oil added marinated anchovies as $14.67 \mathrm{mg} / 100 \mathrm{~g}$ whereas TVB-N value of the control group was $24.10 \mathrm{mg} / 100 \mathrm{~g}$ in the sixth month of storage at $4^{\circ} \mathrm{C}$. TVB-N of a particular fish species depends on the type of fish feeding, the fish size, the season of catching and other environment factor as well as microbial activity. This could explain the difference of other studies with our results (Kilinc et al., 2005a; Ozden et al., 2003).

The $\mathrm{pH}$ value, which greatly affects the enzymatic and microbiological activity is greatly reduced during the marination. The mean $\mathrm{pH}$ value of frozen anchovies was 6.45 and this value decreased significantly after marination down to 3.91-3.82. $\mathrm{pH}$ values of different treatments showed the same trend in which the values decreased initially and then increased. The result might be linked to $\mathrm{CO}_{2}$ in marinated fish samples, glycolysis reactions, resulting in a decrease of $\mathrm{pH}$ value, however, the production of alkaline products such as ammonia and trimethylamine by fish spoilage bacteria led to an increase of $\mathrm{pH}$ value. $\mathrm{pH}$ value had a significant increase in the $7^{\text {th }}$ month and the highest $\mathrm{pH}$ value was observed in hot chilli sauced marinated anchovies. It can be linked with a higher microbiological load of hot chilli sauced samples. In the study, which examined the sensory, chemical and microbiological changes of the anchovy marinades in 7 months of storage at $0-2^{\circ} \mathrm{C}$, it was reported that the $\mathrm{pH}$ of samples ranged from 3.89 to 4.27 while the $\mathrm{pH}$ of raw material was 6.21 (Olgunoglu, 2007).

\section{Microbiological Analysis}

The species and amount of bacteria found in fish vary due to fishing season, fish species, feed, environmental conditions, and fish developmental phase. The initial total viable bacteria count of anchovies was $4.00 \mathrm{log} \mathrm{cfu} / \mathrm{g}$ which is lower than the microbial limit $(7.00 \mathrm{log} \mathrm{cfu} / \mathrm{g})$ prescribed for seafood (ICMSF, 1986). The number of total viable bacteria is an index showing the level of microorganism in the product. In our study, there was a decrease in the total aerobic bacteria number after marination. This decrease in total bacteria level is due to salt and acid used in the marination process. Similar results were reported by (Kilinc et al., 2005b; Verdos et al., 2019). Tomac et al. (2015) reported the initial count of mesophilic bacteria in frozen anchovies as $3.87 \mathrm{log} \mathrm{cfu} / \mathrm{g}, 2.58 \mathrm{log}$ $\mathrm{cfu} / \mathrm{g}$ after marination.

The changes in total viable bacteria count of marinated anchovy samples are given in Figure 2. Total viable bacteria content of marinated anchovies on day 0 were 2.03, 2.55, $2.53 \mathrm{log} \mathrm{cfu} / \mathrm{g}$ for control, garlic added, and hot chilly pepper sauce added samples respectively. Total viable bacteria count decreased along with the storage time (7 months). At the end of 7 months of storage at $4^{\circ} \mathrm{C}$, total viable bacteria count in for control, garlic added and hot chilly pepper sauce added samples were $2.08,1.74,1.90$ respectively.
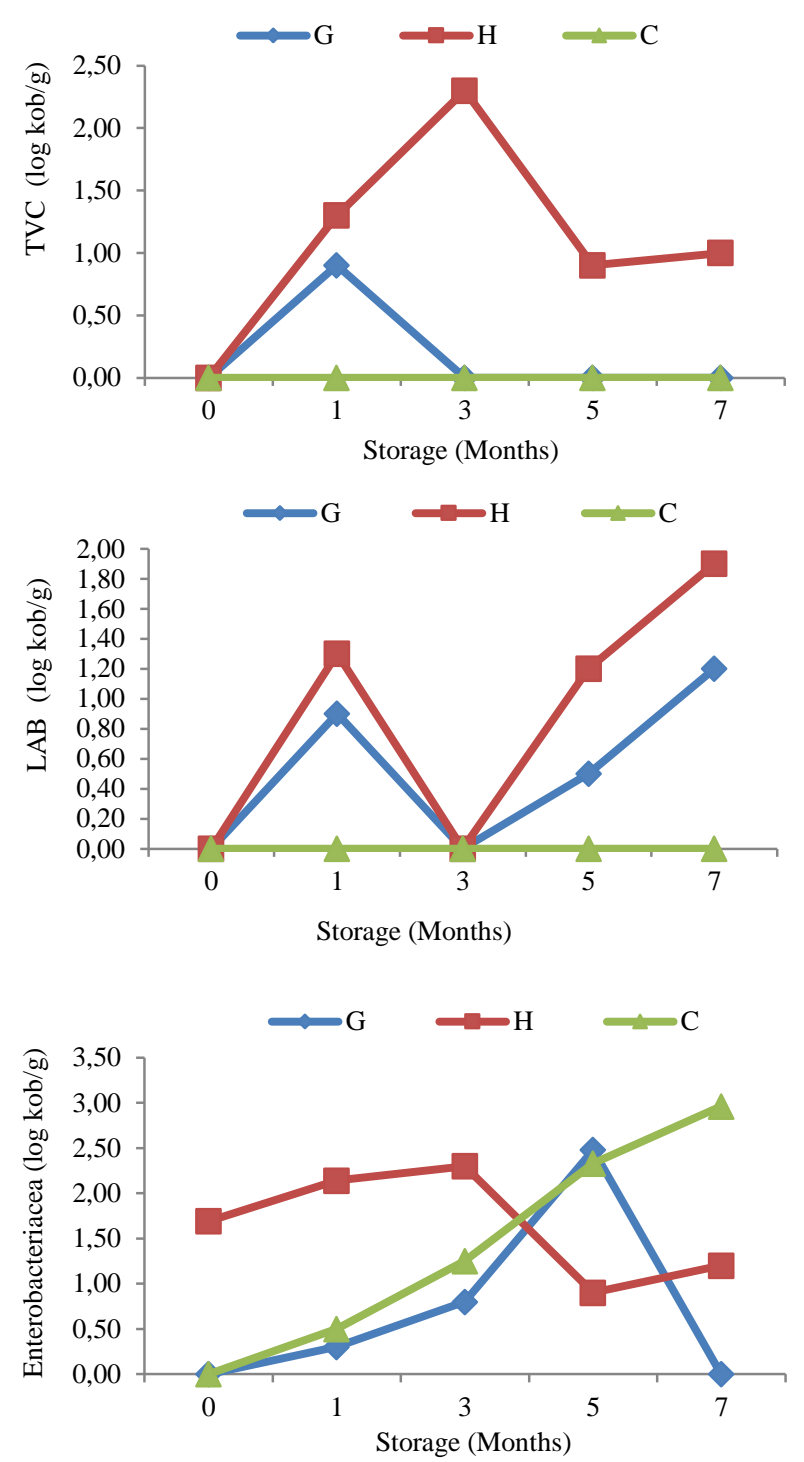

Figure 2. Microbiological profile of marinated anchovies during 7 months of storage at $4^{\circ} \mathrm{C}$

TVC: Total viable bacteria count, LAB: Lactic acid bacteria count C: Marinated anchovies (Control), G: Garlic added marinated anchovies, $\mathrm{H}$ : Hot chilly sauce added marinated anchovies 
Table 3. Biogenic amine analysis results of samples at $4^{\circ} \mathrm{C}$ for 7 months

\begin{tabular}{|c|c|c|c|c|c|c|c|c|c|}
\hline \multirow{2}{*}{ Time } & \multicolumn{3}{|c|}{ Histamine } & \multicolumn{3}{|c|}{ Cadaverine } & \multicolumn{3}{|c|}{ Putrescine } \\
\hline & $\mathrm{C}$ & $\bar{G}$ & $\mathrm{H}$ & $\bar{C}$ & $\bar{G}$ & $\mathrm{H}$ & $\mathrm{C}$ & $\mathrm{G}$ & $\mathrm{H}$ \\
\hline Day 1 & ND & ND & ND & ND & ND & ND & ND & ND & $\begin{array}{l}6.72^{\mathrm{aB}} \\
(2.85)\end{array}$ \\
\hline Month 1 & $\begin{array}{l}2.95^{\mathrm{aB}} \\
(0.11)\end{array}$ & ND & $\begin{array}{c}1.10^{\mathrm{aAB}} \\
(1.56)\end{array}$ & $\begin{array}{c}2.37^{\mathrm{abA}} \\
(0.12)\end{array}$ & $\begin{array}{l}1.09^{\mathrm{aA}} \\
(0.50)\end{array}$ & $\begin{array}{l}1.50^{\mathrm{aA}} \\
(2.11)\end{array}$ & $\begin{array}{l}0.96^{\mathrm{aA}} \\
(0.11)\end{array}$ & $\begin{array}{l}0.46^{\mathrm{aA}} \\
(0.30)\end{array}$ & $\begin{array}{l}3.14^{\mathrm{aA}} \\
(2.37)\end{array}$ \\
\hline Month 2 & $\begin{array}{l}3.98^{\mathrm{aA}} \\
(0.13)\end{array}$ & $\begin{array}{c}2.82^{\mathrm{abA}} \\
(1.20)\end{array}$ & $\begin{array}{l}5.37^{\mathrm{aA}} \\
(3.23)\end{array}$ & $\begin{array}{c}1.86^{\mathrm{abA}} \\
(0.24)\end{array}$ & $\begin{array}{l}1.45^{\mathrm{aA}} \\
(0.86)\end{array}$ & $\begin{array}{l}0.57^{\mathrm{aA}} \\
(0.81)\end{array}$ & $\begin{array}{l}0.84^{\mathrm{aA}} \\
(0.11)\end{array}$ & $\begin{array}{l}0.46^{\mathrm{aA}} \\
(0.64)\end{array}$ & $\begin{array}{l}1.28^{\mathrm{aA}} \\
(1.81)\end{array}$ \\
\hline Month 3 & $\begin{array}{l}6.94^{\mathrm{aA}} \\
(9.81)\end{array}$ & $\begin{array}{l}1.29^{\mathrm{aA}} \\
(1.81)\end{array}$ & $\begin{array}{l}3.89^{\mathrm{aA}} \\
(1.84)\end{array}$ & $\begin{array}{l}3.71^{\mathrm{bA}} \\
(2.38)\end{array}$ & $\begin{array}{l}2.44^{\mathrm{aA}} \\
(0.76)\end{array}$ & $\begin{array}{l}7.00^{\mathrm{aA}} \\
(5.48)\end{array}$ & $\begin{array}{l}0.91^{\mathrm{aA}} \\
(1.28)\end{array}$ & ND & $\begin{array}{l}0.67^{\mathrm{aA}} \\
(0.94)\end{array}$ \\
\hline Month 7 & $\begin{array}{c}11.66^{\mathrm{aA}} \\
(5.80)\end{array}$ & $\begin{array}{l}4.62^{\mathrm{bA}} \\
(1.33)\end{array}$ & $\begin{array}{c}14.67^{\mathrm{bA}} \\
(3.14)\end{array}$ & $\begin{array}{l}4.43^{\mathrm{bA}} \\
(0.93)\end{array}$ & $\begin{array}{l}7.16^{\mathrm{bA}} \\
(1.95)\end{array}$ & $\begin{array}{l}5.34^{\mathrm{aA}} \\
(3.46)\end{array}$ & $\begin{array}{l}6.32^{\mathrm{bB}} \\
(1.26)\end{array}$ & ND & $\begin{array}{c}5.37^{\mathrm{aAB}} \\
(2.74)\end{array}$ \\
\hline \multirow{2}{*}{ Time } & \multicolumn{4}{|c|}{ Tyramine } & \multicolumn{5}{|c|}{ Tryptamine } \\
\hline & $\mathrm{C}$ & & $\mathrm{G}$ & $\mathrm{H}$ & & $\mathrm{C}$ & $\mathrm{G}$ & & $\mathrm{H}$ \\
\hline Day 1 & ND & & ND & $\begin{array}{l}0.95^{\mathrm{aA}} \\
(1.34)\end{array}$ & & ND & $\begin{array}{l}3.66^{\mathrm{aA}} \\
(5.17)\end{array}$ & & ND \\
\hline Month 1 & ND & & ND & $\begin{array}{l}1.37^{\mathrm{aA}} \\
(1.93)\end{array}$ & & ND & $\begin{array}{l}0.77^{\mathrm{aA}} \\
(1.08)\end{array}$ & & $\begin{array}{c}0.94^{\mathrm{aA}} \\
(1.32)\end{array}$ \\
\hline Month 2 & ND & & $\begin{array}{l}0.18^{\mathrm{aA}} \\
(0.25)\end{array}$ & ND & & $\begin{array}{c}14.20^{\mathrm{bA}} \\
(0.24)\end{array}$ & $\begin{array}{l}4.61^{\mathrm{aA}} \\
(6.51)\end{array}$ & & $\begin{array}{l}9.24^{\mathrm{aA}} \\
(0.04)\end{array}$ \\
\hline Month 3 & $\begin{array}{l}15.66^{\mathrm{aA}} \\
(15.06)\end{array}$ & & $\begin{array}{l}0.23^{\mathrm{aA}} \\
(0.32)\end{array}$ & ND & & $\begin{array}{c}18.23^{\mathrm{bA}} \\
(9.57)\end{array}$ & $\begin{array}{l}4.81^{\mathrm{aA}} \\
(0.08)\end{array}$ & & $\begin{array}{c}26.10^{\mathrm{bA}} \\
(9.71)\end{array}$ \\
\hline Month 7 & $\begin{array}{c}12.02^{\mathrm{aA}} \\
(6.39)\end{array}$ & & $\begin{array}{l}2.25^{\mathrm{bA}} \\
(1.06)\end{array}$ & ND & & $\begin{array}{c}22.75^{\mathrm{bA}} \\
(3.32)\end{array}$ & $\begin{array}{l}7.57^{\mathrm{aA}} \\
(3.50)\end{array}$ & & $\begin{array}{l}28.09^{\mathrm{bA}} \\
(10.69)\end{array}$ \\
\hline
\end{tabular}

The results are the average of three replications. The values in parentheses are the standard deviation of the mean. Uppercase (A-B) shows the statistical difference between sample groups, lower case $(\mathrm{a}-\mathrm{b})$ show the statistical difference between months in the same group $(\mathrm{P}<0.05)$.

$7 \mathrm{log} \mathrm{cfu} / \mathrm{g}$ is considered as the highest acceptable limit for total viable bacteria count in fish samples. This level was not reached during the storage period. Initial total viable bacteria count was low compared with other studies (Gunsen et al., 2011; Olgunoglu, 2007). The marination procedure decreases the microbial count even inhibits their growth depending on salt and acid concentration. Freezing delays the growth of bacteria and reduces the microbial count of several bacteria including spoilage and pathogenic bacteria (Alrabadi, 2015). It is reported that the marination process has an inhibitory effect on the bacteria, yeast, mold amount in several foods (Gunsen et al., 2011; Sen et al., 2003).

Enterobacteriaceae count of raw anchovies was 2.05 $\log \mathrm{cfu} / \mathrm{g}$. With the marination process Enterobacteriaceae count decreased due to salt and vinegar. Enterobacteriaceae is often used as a sign of post-process contamination of fecal contamination (Verdos et al., 2019). Enterobacteriaceae count increased till $2^{\text {nd }}$ month of storage and decreased afterward for garlic added group. Enterobacteriaceae count increased steadily to $3 \log \mathrm{cfu} / \mathrm{g}$ in the control group. At the end of storage, Enterobacteriaceae count in hot chilly sauced group was $1.20 \log \mathrm{cfu} / \mathrm{g}$. $\mathrm{pH}$ values of our samples increased up to $2^{\text {nd }}$ month with the microbial activity that is producing alkaline products. In a study done by Gunsen et al. 2011, total coliform bacteria were not detected in marinated anchovies during storage at $4^{\circ} \mathrm{C}$ for 11 months. It was reported that $1.69 \mathrm{log} \mathrm{cfu} / \mathrm{g}$ of coliform bacteria was isolated in marinated anchovy products (Dokuzlu, 1997).

The initial LAB count of raw anchovies was $2 \log \mathrm{cfu} / \mathrm{g}$. $\mathrm{LAB}$ was not detected after the marination process. LAB count of hot chilly sauced marinated anchovies and garlic added marinated anchovies after 7 months of storage at $4^{\circ} \mathrm{C}$ were $1.9 \log \mathrm{cfu} / \mathrm{g}, 1.20 \mathrm{log} \mathrm{cfu} / \mathrm{g}$ respectively. No LAB was detected in the control group throughout the storage period. After 3 months of storage at $4^{\circ} \mathrm{C}$ in salted and marinated sardines (Sardina pilchardus), approximately $2.91 \log \mathrm{cfu} / \mathrm{g}$ LAB was found, but after 6 months of storage higher populations (5.66 log cfu/g) were recorded (Kilinc et al., 2005b). In a study by Fuselli et al. (1994) coliforms, Enterobacteriaceae, psychrotrophic bacteria were not detected after the marination process of anchovies (Engraulis anchoita).

The highest count of total viable bacteria, lactic acid bacteria was found in the products prepared with hot chilli pepper sauce. The reason for this relatively higher microbial count could be explained with the fact that hot chilly pepper sauce is not a sterilized product and some contamination could occur during the filling procedure of products where the sauce is spread on both sides of anchovies.

\section{Biogenic Amines}

The average values of biogenic amines $(\mathrm{mg} / \mathrm{kg})$ during 7 months of storage are presented in Table 3. The results are expressed as the mean \pm standard deviation (SD) of $\mathrm{mg}$ of biogenic amines $/ \mathrm{kg}$. Histamine was undetectable in all of the samples right after the marination procedure. The highest amount of histamine was determined in control groups $(16.89 \mathrm{mg} / \mathrm{kg})$ which is much lower than the limit of histamine concentration $(50 \mathrm{mg} / \mathrm{kg})$ recommended by (FDA, 2011) for Scombridae family. Histamine amount increased in all of the groups throughout the storage. No significant difference was seen between $\mathrm{C}$, and $\mathrm{G}, \mathrm{H}$ groups at the end of 7 months of storage at $4^{\circ} \mathrm{C}$. In a study done by Olgunoglu (2007), the changes of histamine were investigated during storage at $0-2^{\circ} \mathrm{C}$ for 7 months and from day 0 to month 7 , histamine amount increased from 8.00 $\mathrm{mg} / \mathrm{kg}$ to $34.50 \mathrm{mg} / \mathrm{kg}$. Biogenic amine values of marinated 
shad fillets stored in brine, oil and vacuum packages were examined and the mean histamine amount in the samples at the beginning of storage was reported as $1.30 \mathrm{mg} / \mathrm{kg}$ (Erdem et al., 2017).

Garlic was effective in reducing the histamine amount in marinated anchovies. Gunsen et al. (2011) reported that histamine levels were $5.52 \mathrm{mg} / \mathrm{kg}$ at $1^{\text {st }}$ day of storage and $12.85 \mathrm{mg} / \mathrm{kg}$ on the $4^{\text {th }}$ month of storage at $4^{\circ} \mathrm{C}$. Putrescine and cadaverine are indicated as potentiators of histamine in case of scombroid fish poisoning. The maximum tolerable level of cadaverine in fish is reported as $510 \mathrm{mg} / \mathrm{kg}$ (Rauscher-Gabernig et al., 2012). Cadaverine was not detected in marinated anchovy groups on day 0 . In parallel with the storage time, the cadaverine amount increased in all of the groups.

During the storage period of 7 months, the amount of putrescine was determined at very low levels (ND-7.31 $\mathrm{mg} / \mathrm{kg}$ ) in all of the samples. With the antimicrobial activities, garlic addition was effective in reducing the putrescine amount (Mah et al., 2009) which is in agreement with our results. Rauscher-Gabernig et al. (2012) reported a daily tolerable putrescine level of $170 \mathrm{mg} / \mathrm{kg}$. This limit value is not reached in all sample groups during storage within the scope of our study.

Tyramine is a monoamine formed by the cleavage of the tyrosine amino acid and is referred to as para-tyramine, 4-hydroxyphenethylamine, or p-tyramine. Although there is no limit to the maximum amount of tyramine present in foods, it has been reported that the level of occurrence of adverse side effects for human health varies between 600 $\mathrm{mg} / \mathrm{kg}$ and $2000 \mathrm{mg} / \mathrm{kg}$ in different studies. The mean highest tyramine value was determined as $15.66 \mathrm{mg} / \mathrm{kg}$ in the $3^{\text {rd }}$ month of storage in the control group. Tyramine values determined at the end of the storage were found to be statistically $(\mathrm{P}>0.05)$ different. Highest tyramine values were detected in the control group. Garlic was efficient in reducing tyramine levels in marinated anchovies. During storage at $4^{\circ} \mathrm{C}$, toxic levels were not reached in all of the sample groups.

There are no legal regulations about tryptamine contents in food, while ingestion of high contents of this amine could potentiate hypertensive crises in patients treated with MAOI drugs (Joosten, 1988). The highest tryptamine was found in the $7^{\text {th }}$ month of storage in hot chilli sauced samples.

\section{Conclusions}

Our results demonstrate that sauces or garlic adding doesn't influence the microbial load at the end of storage time since the marination process is efficient in prolonging the shelf life of fish. The maximum microbiological limit for the total aerobic bacterial counts in fish and fish products is recommended as $10^{7} \mathrm{cfu} \mathrm{g}^{-1}$ (ICMSF, 1986). All of the samples were below this limit. Lowest TBA, TVB-N, and $\mathrm{pH}$ values were determined in the garlic added group. Garlic was efficient in retarding lipid oxidation. Hot chilly pepper sauced samples and control samples had no significant difference $(\mathrm{P}>0.05)$ considering TBA and TVB$\mathrm{N}$ values. Histamine, cadaverine, putrescine, tyramine, and tryptamine values of samples were measured. During storage at $4^{\circ} \mathrm{C}$ for 7 months, the histamine was lower than limit value set by the FDA $(50 \mathrm{mg} / \mathrm{kg})$ in all sample groups.
Histamine was not found in all of the sample groups at the beginning of storage. The lowest histamine value at the end of storage was determined in garlic added samples with $4.62 \mathrm{mg} / \mathrm{kg}$. The cadaverine was not detected in all of the sample groups at the beginning of the storage and the cadaverine values at the end of the storage were not statistically different $(\mathrm{P}>0.05)$ between sample groups. At the beginning of storage, putrescine was determined only in hot pepper chilly sauced samples. At the end of storage, putrescine was not detected in garlic added samples and statistically a significant difference $(\mathrm{P}<0.05)$ was observed with other groups. On average, $0.95 \mathrm{mg} / \mathrm{kg}$ of tyramine was measured in the samples with hot chilly pepper sauce at the beginning of the storage. At the end of the storage, in the control group and garlic added group, an average of 12.02 and $2.25 \mathrm{mg} / \mathrm{kg}$ tyramine was determined respectively. In hot chilly pepper sauced samples, tyramine could not be determined at the end of 7 months storage at $4^{\circ} \mathrm{C}$. Tryptamine is a biogenic amine produced from the tryptophan amino acid. In our study, the highest tryptamine levels were observed in hot chilly pepper sauced samples. As a result, the addition of garlic led to lower values of TBA, TVB-N values. It also halted microbial growth and caused some biogenic amines (histamine, putrescine, tryptamine) to be detected in lower amounts.

\section{References}

Alrabadi NI. 2015. The Effect of Freezing on Different Bacterial Counts in Raw Milk. International Journal of Biology, 4: 912.

Antonacopoulos N. Vyncke W. 1989. Determination of volatile basic nitrogen in fish - a 3rd collaborative study by the westeuropean-fish-technologists association (wefta). Zeitschrift Fur Lebensmittel-Untersuchung Und-Forschung, 309-316.

AOAC. 1990. Official Methods of Analysis of the Association of Official Analytical Chemists (15th ed.). Arlington, VA.

AOAC. 2000. 17th edition. Washington DC.

AOAC. 2002a. 981.10 Protein synthesis in meat and meat products. Washington DC.: AOAC.

AOAC. 2002b. Official Methods of Analysis Washington DC.

Arik F. Fiedler F. Lukowiez MV. Sperner B. 2002. Untersuchungen zurhaltbarkeit von be-und verarbeiteten susswasserfischen. Archiv Fur Lebensmittelhygiene, 34-39.

Baygar T. Alparslan Y. Kaplan M. 2012. Determination of changes in chemical and sensory quality of sea bass marinades stored at+4 (+/- 1)degrees $\mathrm{C}$ in marinating solution. Cyta-Journal of Food, 3: 196-200. 10.1080/19476337.2011.614016

Dokuzlu C. 1997. The Effects of Acid-Salt Ratio Used in the Production of Marinated Anchovy to the Microbiologic, Organoleptic Quality and Determination of Shelf life of the Product. Pendik Vet. Mikrobiol. Derg., 81-90.

Duyar HA. Eke E. 2009. Production and Quality Determination of Marinade from Different Fish Species. Journal of Animal and Veterinary Advances, 2: 270-275.

Eerola S. Maijala R. Sagues AXR. Salminen M. Hirvi T. 1996. Biogenic amines in dry sausages as affected by starter culture and contaminant amine-positive Lactobacillus. Journal of Food Science, 6: 1243-1246.

Erdem EM. Koral S. Işıdan S. 2017. The Effect of Different Packaging Methods on Microbiological Quality Criteria and Changes in Biogenic Amines of Marinated Shad (Alos

immaculata, Bennett, 1838). Journal of Agricultural Sciences, 404-414. 
FDA. 2011. Scombrotoxin (histamine) formation. Fish and fishery products hazards and control guide. Washington, DC Department of Health and Human Service, Public Health Service, Food and Drug Administration, Center for Food Safety and Applied Nutrition, Office of Seafood,.

Fuselli SR. Casales MR. Fritz R. Yeannes MI. 1994 Microbiology of the marination process used in anchovy (Engraulis anchoita) production. Food Science and Technology, 214-218.

Gomes HDA. da Silva EN. do Nascimento MRL. Fukuma HT. 2003. Evaluation of the 2-thiobarbituric acid method for the measurement of lipid oxidation in mechanically deboned gamma irradiated chicken meat. Food Chemistry, 3: 433-437.

Goulas AE. Kontominas MG. 2007. Combined effect of light salting, modified atmosphere packaging and oregano essential oil on the shelf-life of sea bream (Sparus aurata): Biochemical and sensory attributes. Food Chemistry, 1: 287296. 10.1016/j.foodchem.2005.09.045

Gunsen U. Ozcan A. Aydin A. 2011. Determination of Some Quality Criteria of Cold Storaged Marinated Anchovy under Vacuum and Modified Atmosphere Conditions. Turkish Journal of Fisheries and Aquatic Sciences, 2: 233-242.

ICMSF. 1986. International commission on microbiological specifications for foods. Toronto/Canada: University of Toronto Press.

İnanlı Güral A. Özpolat E. Emir Çoban Ö. Karaton N. 2010. Chemical composition of marinated anchovy (Engraulis encrasicolus L., 1758) and sensory evaluation in different sauce. Journal of Fisheries Sciences, 4: 455-461.

Joosten HMLJ. 1988. The biogenic amine contents of Dutch cheese and their toxicological significance. Netherland Milk Dairy Journal, 25-42.

Karami B. Moradi Y. Motallebi AA. Hosseini E. Soltani M. 2013. Effects of frozen storage on fatty acids profile, chemical quality indices and sensory properties of red tilapia (Oreochromis niloticus x Tilapia mosambicus) fillets. Iranian Journal of Fisheries Sciences, 2: 378-388.

Kilinc B. Cakli S. 2005a. Chemical, enzymatical and textural changes during marination and storage period of sardine (Sardina pilchardus) marinades. European Food Research and Technology, 6: 821-827. 10.1007/s00217-005-0114-y

Kilinc B. Cakli S. 2005b. Determination of the shelf life of sardine (Sardina pilchardus) marinades in tomato sauce stored at 4 degrees C. Food Control, 7: 639-644.

Kocatepe D. Turan H. Altan C. O. Keskin I. Ceylan A. Kostekli B. Candan C. 2019. Influence of different essential oils on marinated anchovy (Engraulis encrasicolus L. 1758) during refrigerated storage. Food Science and Technology, 255-260. $10.1590 /$ fst.01318
Mah JH. Kim YJ. Hwang HJ. 2009. Inhibitory effects of garlic and other spices on biogenic amine production in Myeolchijeot, Korean salted and fermented anchovy product. Food Control, 5: 449-454.

Oksuz A. Ozyilmaz A. 2010. Changes in Fatty Acid Compositions of Black Sea Anchovy (Engraulis encrasicolus L. 1758) During Catching Season. Turkish Journal of Fisheries and Aquatic Sciences, 3: 381-385.

Olgunoglu Aİ. 2007. Marine Edilmiş Hamside (Engraulis Engrasicholus L., 1758) Duyusal, Kimyasal Ve Mikrobiyolojik Değişimler (Doktora), Çukurova Üniversitesi, Adana.

Ozden O. 2005. Changes in amino acid and fatty acid composition during shelf-life of marinated fish. Journal of the Science of Food and Agriculture, 12: 2015-2020.

Ozden O. Baygar T. 2003. The effect of different packaging methods on some quality criteria of marinated fish. Turkish Journal of Veterinary \& Animal Sciences, 4: 899-906.

Rauscher-Gabernig E. Gabernig R. Brueller W. Grossgut R. Bauer F. Paulsen P. 2012. Dietary exposure assessment of putrescine and cadaverine and derivation of tolerable levels in selected foods consumed in Austria. European Food Research and Technology, 2: 209-220. 10.1007/s00217-0121748-1

Schormüller. 1969. Handbuch der Lebensmittelchemie (Band III/2). Berlin/Hidelberg.

Sen MKC. Temelli S. 2003. Microbiological and chemical qualities of marinated anchovy prepared with different vegetable additives and sauce. Revue De Medecine Veterinaire, 11: 703-707.

Tarladgis BG. Watts BM. Dugan LRJ. 1960. A distillation method for the quantitative determination of malonaldehyde in rancid foods. Journal of American Oil Chemists Society, 44-48.

Tomac A. Yeannes MI. 2015. Quality Changes in Gamma Irradiated Marinades of Anchovy (Engraulis anchoita) During Refrigerated Storage. Journal of Aquatic Food Product Technology, 7: 686-697.

TUİK. 2018. 2018 Su Ürünleri İstatistikleri.

Turhan S. Sagir I. Temiz H. 2009. Oxidative stability of brined anchovies (Engraulis encrasicholus) with plant extracts. International Journal of Food Science and Technology, 2: 386-393.

Verdos GI. Makrigiannis A. Tsigaras E. Boziaris IS. 2019. Survival of food-borne bacterial pathogens in traditional Mediterranean anchovy products. Journal of Food Safety, 1. 